\title{
B Cells from Patients with Systemic Lupus Erythematosus Display Abnormal Antigen Receptor-mediated Early Signal Transduction Events
}

\author{
Stamatis-Nick C. Liossis, ${ }^{*}$ Birgit Kovacs, ${ }^{\star}$ Greg Dennis, ${ }^{\ddagger}$ Gary M. Kammer, ${ }^{\S}$ and George C. Tsokos ${ }^{\star \ddagger}$ \\ $*$ Department of Clinical Physiology, Walter Reed Army Institute of Research, Washington, DC 20307-5100; ${ }^{\ddagger}$ Departments of Clinical \\ Investigation and Medicine, Walter Reed Army Medical Center, Washington, DC 20307-5001; and ${ }^{\S}$ Department of Medicine, Bowman \\ Gray School of Medicine, Wake Forest University, Winston-Salem, North Carolina 27157-1058
}

\begin{abstract}
To understand the molecular mechanisms that are responsible for the B cell overactivity that is observed in patients with SLE, we have conducted experiments in which the surface immunoglobulin (sIg)-mediated early cell signaling events were studied. The anti-sIgM-mediated free intracytoplasmic calcium $\left(\left[\mathrm{Ca}^{2+}\right]_{i}\right)$ responses were significantly higher in SLE B cells compared with responses of normal individuals and to those of patients with other systemic autoimmune rheumatic diseases. The anti-IgD $\mathrm{mAb}$ induced $\left[\mathrm{Ca}^{2+}\right]_{i}$ responses were also higher in lupus $\mathrm{B}$ cells than in controls. The magnitude of anti-sIgM-mediated $\mathrm{Ca}^{2+}$ release from intracellular stores was also increased in B cells from SLE patients compared with normal controls. The amount of inositol phosphate metabolites produced upon crosslinking of sIgM was slightly higher in patients with lupus than in normal controls, although the difference was not statistically significant. In contrast, the degree of antisIgM-induced protein tyrosine phosphorylation was obviously increased in lupus patients. Our study demonstrates clearly for the first time that SLE B cells exhibit aberrant early signal transduction events, including augmented calcium responses after crosslinking of the $\mathrm{B}$ cell receptor and increased antigen-receptor-mediated phosphorylation of protein tyrosine residues. Because the above abnormalities did not correlate with disease activity or treatment status, we propose that they may have pathogenic significance. ( $J$. Clin. Invest. 1996. 98:2549-2557.) Key words: lymphocyte signaling - calcium responses - tyrosine phosphorylation • inositol phosphate metabolites $\bullet$ human autoimmunity
\end{abstract}

\section{Introduction}

SLE is considered to be the archetypal human autoimmune disease, and it is characterized by a variety of abnormalities of the immune system $(1,2)$. Both in human (3) and in murine models of the disease (4), B cell overactivity is considered to be responsible for the hypergammaglobulinemia and the pro-

Address correspondence to George C. Tsokos, Department of Clinical Physiology, Bldg. 40, Rm. 3078, Walter Reed Army Institute of Research, Washington, DC 20307-5100. Phone: 202-782-9146; FAX: 202-782-3160; E-mail: gtsokos@mem.po.com

Received for publication 21 August 1996 and accepted in revised form 2 October 1996.

J. Clin. Invest.

(C) The American Society for Clinical Investigation, Inc.

0021-9738/96/12/2549/09 \$2.00

Volume 98, Number 11, December 1996, 2549-2557 duction of a large variety of autoantibodies, some of which are convincingly involved in the pathogenesis of certain types of immune complex-mediated histological damage (5, 6). Different factors contribute to lupus B cell overactivity. Among these are defective suppressor/inducer T cell subset (7), excessive help provided by certain T cell subsets $(8,9)$, defective Fcy receptor-mediated suppression (10), and overreactivity to cytokines delivered to B cells in an endocrine, paracrine, or autocrine fashion $(11,12)$.

$\mathrm{B}$ cell function itself has so far been considered to be intact, but the conclusion that B lymphocytes are not intrinsically defective has been inferred indirectly (13-15). Recent evidence produced from the study of murine models suggests that B cells may be intrinsically defective (16-20). To further investigate possible inherent lupus B cell abnormalities, we examined a central aspect of their function, namely the early events of the $\mathrm{B}$ cell receptor $(\mathrm{BCR})^{1}$-mediated signal transduction.

Stimulation of B cells with antigens (Ags) or mAbs results in a well-regulated cascade of intracellular events, which lead to cell activation and proliferation. The ligation of the BCR complex initially causes the activation of protein tyrosine kinases (PTK) $(21,22)$ which, in turn, induces among other events the phosphorylation and activation of phospholipase $\mathrm{C}$ (PLC) isozymes PLC $\gamma 1$ and PLC $\gamma 2$. The latter PLC isozyme predominates in B cells (23). Activated PLC acts on membrane phosphatidylinositol 4,5-biphosphate $\left(\mathrm{PIP}_{2}\right)$ that leads to the production of diacylglycerol (DAG) and inositol 1,4,5trisphosphate $\left(\mathrm{InsP}_{3}\right)$ (24-26). DAG activates protein kinase $\mathrm{C}$ (PKC) (27), whereas $\mathrm{InsP}_{3}$ binds to its receptor on the endoplasmic reticulum and causes the release of free $\mathrm{Ca}^{2+}$ from intracellular stores (28). The increase of free intracytoplasmic $\mathrm{Ca}^{2+}$ concentration $\left(\left[\mathrm{Ca}^{2+}\right]_{\mathrm{i}}\right)$ and activated $\mathrm{PKC}$ act on a variety of genes, resulting in their transcription, cellular activation, and proliferation $(29,30) . \mathrm{Ca}^{2+}$ is an important intracellular messenger which plays a role in a spectrum of cellular events that range from egg fertilization to apoptosis, via the regulation of signal transduction (31-35).

The BCR-complex-mediated early signal transduction events in lupus have not been investigated so far. In this communication, we present studies in which we examined the BCR-initiated $\left[\mathrm{Ca}^{2+}\right]_{\mathrm{i}}$ responses, tyrosine phosphorylation and $\mathrm{InsP}_{3}$ production in fresh, unmanipulated $\mathrm{B}$ cells from SLE patients, disease and normal controls. Our results show that only

1. Abbreviations used in this paper: $\mathrm{BCR}, \mathrm{B}$ cell receptor; $\left[\mathrm{Ca}^{2+}\right]_{\mathrm{i}}$, free intracytoplasmic concentration of $\mathrm{Ca}^{2+}$; $\mathrm{HRPO}$, horseradish peroxidase; $\mathrm{InsP}_{1}$, inositol phosphate-1; $\mathrm{InsP}_{2}$, Ins phosphate-2; InsP $\mathrm{P}_{3}$, Ins 1,4,5-triphosphate; $\operatorname{InsP}_{3} \mathrm{R}$, InsP $\mathrm{P}_{3}$ receptor; ITAM, $\operatorname{Ig}$ (superfamily) tyrosine-based activation motif; PKA, protein kinase A; PKC, protein kinase C; PTK, protein tyrosine kinase; sIg, surface Ig. 
lupus B cells display aberrant BCR-induced early cell signaling events, which may contribute to the abnormal function of SLE B cells.

\section{Methods}

Patients and controls. 21 SLE patients (18 women, 3 men) were studied. All subjects fulfilled at least 4 of the 11 revised criteria of the American Rheumatism Association for the Classification of SLE (36). The age of the patients ranged from 20 to $76 \mathrm{yr}($ mean $\pm \mathrm{SD}=$ $44 \pm 14.2$ ). Patients who were receiving glucocorticoids were studied at least $24 \mathrm{~h}$ after their last dose. Disease activity was measured using the SLEDAI score (37) (mean \pm SD $=6.4 \pm 5.7)$. 15 patients were on prednisone, 13 on hydroxychloroquine, and 4 were on cytotoxic medications ( 1 on cyclophosphamide, 1 on methotrexate, and 2 were receiving azathioprine). An additional sample of 12 patients with other systemic autoimmune rheumatic diseases (disease-control group) was also studied. Of those patients, nine had rheumatoid arthritis, one had juvenile chronic arthritis, one had systemic sclerosis, and one had an undifferentiated connective tissue disease. Of these, 10 were women and 2 were men. The age range was similar to that of the SLE patient group (mean $\pm \mathrm{SD}=43 \pm 14.5$ ). The protocol was approved by the Health Use Committee at Walter Reed Army Medical Center or the Bowman Gray School of Medicine, and informed consent was obtained from all patients. 17 healthy volunteers were included in the control group.

Cells. Heparinized peripheral venous blood was obtained from study subjects. Leukopheresis samples were obtained from several healthy control individuals as well as certain SLE patients. PBMC were obtained by standard Ficoll-Hypaque gradient centrifugation. In most instances, this cell population was enriched in B cells by rosetting once or twice with sheep red blood cells, as described (38). Monocytes were depleted by adherence to plastic (39). The cell population was rested overnight in a concentration of $1 \times 10^{6} \mathrm{cells} / \mathrm{ml}$ in RPMI-1640 containing 10\% FCS.

Reagents and $m A b s$. The $\mathrm{F}\left(\mathrm{ab}^{\prime}\right)_{2}$ fragment of an affinity-purified goat anti-human $\mu$ heavy chain Ab (Jackson Immunoresearch Laboratories Inc., Avondale, PA), and two murine anti-human IgD monoclonal antibodies, ( CBDA-4E5-4C7 and 8IAG.2, both were generous gifts of Dr. Fred Finkelman) were used for the stimulation of lymphocytes. The fluorochrome-conjugated $\mathrm{mAbs}$ used were: anti-CD3 (IgG1)-FITC (Coulter, Hialeah, FL), anti-CD16 (Leu-11c)-phycoerythrin (PE) (a murine IgG1 mAb) and anti-CD14 (Leu-M3)-PE, (murine IgG2b mAb) (Becton-Dickinson Immunocytometry Systems, San Jose, CA). The antiphosphotyrosine horseradish peroxidase (HRPO)-conjugated $\mathrm{mAb}$ (4G10) was purchased from Upstate Biotechnology Inc. (Lake Placid, NY). The dye Indo-1 acetoxy methylester (Molecular Probes, Eugene, OR) was dissolved in DMSO and stored at $-70^{\circ} \mathrm{C}$ until use. Ficoll (Lymphoprep; Nycomed Pharma AS, Oslo, Norway), BSA, EGTA, DMSO, lithium chloride, calcium chloride, sodium formate, formic acid, disodium tetraborate, and ammonium formate were purchased from Sigma Chemical Co. (St. Louis, MO). Chloroform was purchased from J.T. Baker Chemical Company (Phillipsburg, NJ), methanol was purchased from Mallinkrodt (Paris, KY), and RPMI-1640, FCS, glutamine, streptomycin, penicillin, HBSS and Hepes were purchased from Life Technologies (Grand Island, NY).

$\left[\mathrm{Ca}^{2+}\right]_{i}$ measurement using flow cytometry. Cells were suspended at $5 \times 10^{6} \mathrm{cells} / \mathrm{ml}$ in RPMI-1640 supplemented with $2 \mathrm{mM}$ glutamine, $100 \mu \mathrm{g} / \mathrm{ml}$ streptomycin, $100 \mathrm{U} / \mathrm{ml}$ penicillin, $25 \mathrm{mM}$ Hepes, $\mathrm{pH} 7.4$, and $0.1 \%$ FCS. The fluorescent dye Indo- 1 acetoxy methylester (Indo-1 AM) was used to measure the $\left[\mathrm{Ca}^{2+}\right]_{\mathrm{i}}$, as previously described $(40,41)$. At the beginning of each analysis, gating was performed on the lymphocyte population in order to select negatively the B cell subpopulation. $\mathrm{T}$ cells (stained with CD3-FITC mAb), monocytes (stained with CD 14-PE mAb) and natural killer cells (stained with
CD 16-PE mAb) were gated out as previously described (42). For the first $60 \mathrm{~s}$ the cells were left to run unstimulated to record their base fluorescence ratio, which represents the resting $\left[\mathrm{Ca}^{2+}\right]_{i}$ levels. Cells were then stimulated with an anti-sIg $\mathrm{mAb}$ and left to run for a total of $10 \mathrm{~min}$. Data were analyzed using the Multitime analysis program (Phoenix Flow Systems, San Diego, CA). In all experiments, the mean fluorescence ratio for the negatively selected subpopulation was plotted over time and the mean peak/base ratios were recorded.

Dose-response curves. To define the dose of the stimulus that causes the optimal $\mathrm{Ca}^{2+}$ mobilization response, we used increasing doses of all three Abs to stimulate normal PBMC, recorded the peak fluorescence ratio of $\mathrm{Ca}^{2+}$ obtained for each dose as described above, and constructed a curve. The doses used were: $2 \mu \mathrm{g} / \mathrm{ml}, 10 \mu \mathrm{g} / \mathrm{ml}$, $20 \mu \mathrm{g} / \mathrm{ml}, 40 \mu \mathrm{g} / \mathrm{ml}$, and $100 \mu \mathrm{g} / \mathrm{ml}$ for each used $\mathrm{Ab}$.

Inositol phosphate metabolite measurement. The inositol phosphate metabolites were measured as previously described (43) with minor modifications. Briefly, PBMC were washed twice with HBSS supplemented with $25 \mathrm{mM}$ Hepes, antibiotics, and $1 \mathrm{mg} / \mathrm{ml}$ BSA. They were incubated overnight at a concentration of $10 \times 10^{6} \mathrm{cells} / \mathrm{ml}$ in RPMI-1640 supplemented with $10 \%$ FCS, $50 \mu \mathrm{Ci} / \mathrm{ml}$ myo-[1,2${ }^{3} \mathrm{H}$ ]inositol (sp act $18.3 \mathrm{Ci} / \mathrm{mmol}$; DuPont NEN, Boston, MA), antibiotics, $25 \mathrm{mM}$ Hepes, and $2 \mathrm{mM}$ glutamine in a humidified, $5 \% \mathrm{CO}_{2}$ atmosphere incubator. Next, cells were washed twice with HBSS containing $25 \mathrm{mM}$ Hepes, antibiotics, $1 \mathrm{mg} / \mathrm{ml} \mathrm{BSA}$, and $10 \mathrm{mM} \mathrm{LiCl}$, and then resuspended at $15 \times 10^{6}$ cells $/ \mathrm{ml}(0.2 \mathrm{ml}$ final volume $)$ in RPMI-1640, $25 \mathrm{mM}$ Hepes, $1 \mathrm{mg} / \mathrm{ml} \mathrm{BSA}$, and $10 \mathrm{mM} \mathrm{LiCl}$, and incubated at $37^{\circ} \mathrm{C}$ for $15 \mathrm{~min}$. Subsequently, cells were stimulated with the $\mathrm{F}\left(\mathrm{ab}^{\prime}\right)_{2}$ fragment of a goat anti-human $\mu$ chain $(20 \mu \mathrm{g})$ or medium $(0.02 \mathrm{ml})$ for different time periods at $37^{\circ} \mathrm{C}$. The reaction was terminated by the addition of $0.75 \mathrm{ml}$ of chloroform/methanol (1:2) followed by $0.25 \mathrm{ml}$ of water and $0.25 \mathrm{ml}$ of chloroform, as described (43). A $0.2-\mathrm{ml}$ portion of the upper-phase, which contained the watersoluble inositol phosphates (InsP) was diluted first with $2.3 \mathrm{ml}$ of water and was then applied to anion-exchange columns, prepared with AG 1-X8 formate form resin (100-200 mesh; Bio-Rad Laboratories, Richmond, CA).

The columns were washed, the different InsP metabolites were eluted and the amount of radioactivity was measured as described (41). Levels of the different InsP metabolites are expressed as percentage of increase of the specific metabolite in $3 \times 10^{6}$ cells stimulated with the $\mathrm{Ab}$ compared with cells stimulated for the same time with medium alone.

Antiphosphotyrosine immunoblotting. Five million enriched B cells suspended in $0.5 \mathrm{ml}$ volume of RPMI-1640, $10 \%$ FCS were incubated at $37^{\circ} \mathrm{C}$ for $30 \mathrm{~min} .20 \mu \mathrm{g}$ of a $\mathrm{F}\left(\mathrm{ab}^{\prime}\right)_{2}$ fragment of a goat antihuman $\mu$ chain or medium $(0.02 \mathrm{ml})$ was added to the cells at $37^{\circ} \mathrm{C}$, and the reaction was terminated after $60 \mathrm{~s}$ by the addition of $1 \mathrm{ml}$ of ice-cold stop buffer ( $10 \mathrm{mM}$ Tris, $50 \mathrm{mM} \mathrm{NaCl}, 5 \mathrm{mM}$ EDTA) containing various protease inhibitors. The sample was centrifuged for 1 min at $11,000 \mathrm{~g}$ at $4^{\circ} \mathrm{C}$, and the pellet was lysed with sonication in 0.1 $\mathrm{ml}$ of stop buffer containing $1 \%$ Triton X-100. After centrifugation at $12,000 \mathrm{~g}$ for $15 \mathrm{~min}$ at $4^{\circ} \mathrm{C}$, insoluble material was removed and the protein content of the lysates was determined using the Bio-Rad protein assay (Bio-Rad, Hercules, CA) according to the manufacturer's instructions. Protein $(30 \mu \mathrm{g})$ from each lysate was resolved by $10 \%$ polyacrylamide/SDS gel electrophoresis. Resolved proteins from the gels were transferred onto nitrocellulose membranes using a semi-dry transfer system. The membrane was blocked for $2 \mathrm{~h}$ with Tris-buffered saline, $2 \% \mathrm{BSA}$ and $0.25 \%$ Tween. It was then washed and incubated overnight with 1:1,000 dilution of an HRPO-conjugated antiphosphotyrosine $\mathrm{mAb}$ in Tris-buffered saline, $1 \%$ BSA, $0.25 \%$ Tween. After washing, the tyrosine-phosphorylated proteins were detected using the enhanced chemiluminescence detection system (Amersham Life Sciences, Buckinghamshire, UK), according to the manufacturer's instructions.

Statistical analysis. The two-tailed unpaired Student's $t$ test was used to analyze the data. The mean \pm SEM were used for data expression. Values of $P \leq 0.05$ were considered as significant. 

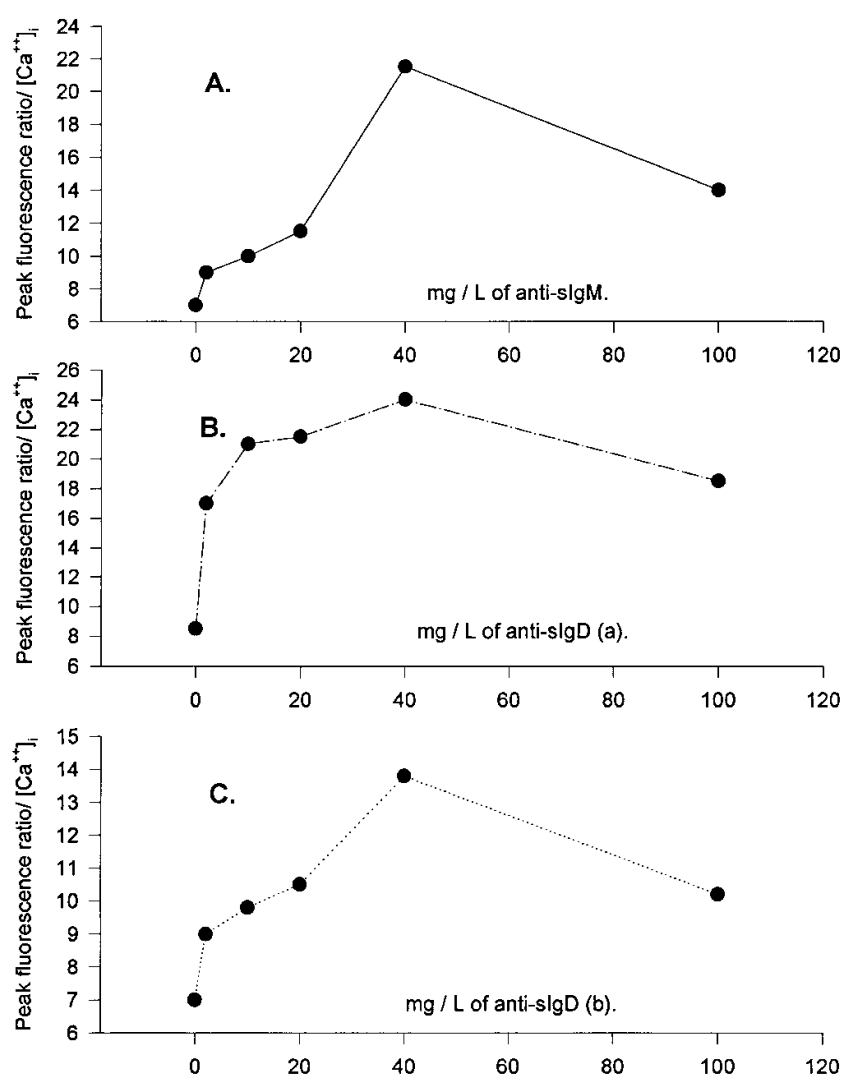

Figure 1. Dose-response curves of anti-sIg-induced increases in $\left[\mathrm{Ca}^{2+}\right]_{\mathrm{i}}$. Three anti-sIg Abs were used in increasing concentrations to stimulate B cell-enriched PBMC from healthy individuals. The $\mathrm{F}\left(\mathrm{ab}^{\prime}\right)_{2}$ fragment of a goat anti-human $\mu$ heavy chain $\mathrm{Ab}(A)$, the 8IAG.2 murine anti-human IgD mAb $(B)$, and the CBDA-4E5-4C7 murine anti-human $\mathrm{IgD} \mathrm{mAb}(C)$, produced maximal peaks of $\left[\mathrm{Ca}^{2+}\right]_{\mathrm{i}}$ at concentrations of $40 \mu \mathrm{g} / \mathrm{ml}$ each. $\left[\mathrm{Ca}^{2+}\right]_{\mathrm{i}}$ was measured as the fluorescence ratio $(381 / 525 \mathrm{~nm})$.

\section{Results}

$S L E$ B cells display higher BCR-mediated $\left[\mathrm{Ca}^{2+}\right]_{i}$ responses than $B$ cells from normal individuals and patients with other systemic autoimmune rheumatic diseases. Five million PBMC enriched in B cells were loaded with the calcium-binding dye Indo-1 AM and stained with anti-CD3-FITC, anti-CD14-PE, and anti-CD16-PE to gate out T cells, monocytes, and natural killer cells, respectively. This negative selection enabled us to measure changes in the levels of $\left[\mathrm{Ca}^{2+}\right]_{i}$, in fresh, unmanipulated B cells which were the only unstained cells in the lymphocyte subpopulation. Stimulation of cells was performed with an $\mathrm{F}\left(\mathrm{ab}^{\prime}\right)_{2}$ fragment of goat-anti-human $\mu$ chain $\mathrm{Ab}$ at 40 $\mu \mathrm{g} / \mathrm{ml}$, which was found to be the optimal concentration for inducing maximal $\left[\mathrm{Ca}^{2+}\right]_{\mathrm{i}}$ responses in normal $\mathrm{B}$ cells (Fig. $1 A$ ). A representative experiment is shown in Fig. $2 A$. The baseline and peak $\left[\mathrm{Ca}^{2+}\right]_{\mathrm{i}}$ responses were recorded in samples from 21 SLE patients, 14 patients with other autoimmune rheumatic diseases, and 17 healthy individuals. There were no significant differences when the resting $\left[\mathrm{Ca}^{2+}\right]_{i}$ recordings of the lupus patients $(7.27 \pm 0.32)$ and the normal group (7.30 \pm 0.27$)$ were compared $(P<0.95)$, or between the disease-control $(6.85 \pm 0.38)$ and the SLE group $(P<0.43)$, or between the normal group and the nonlupus patients $(P<0.35)$.

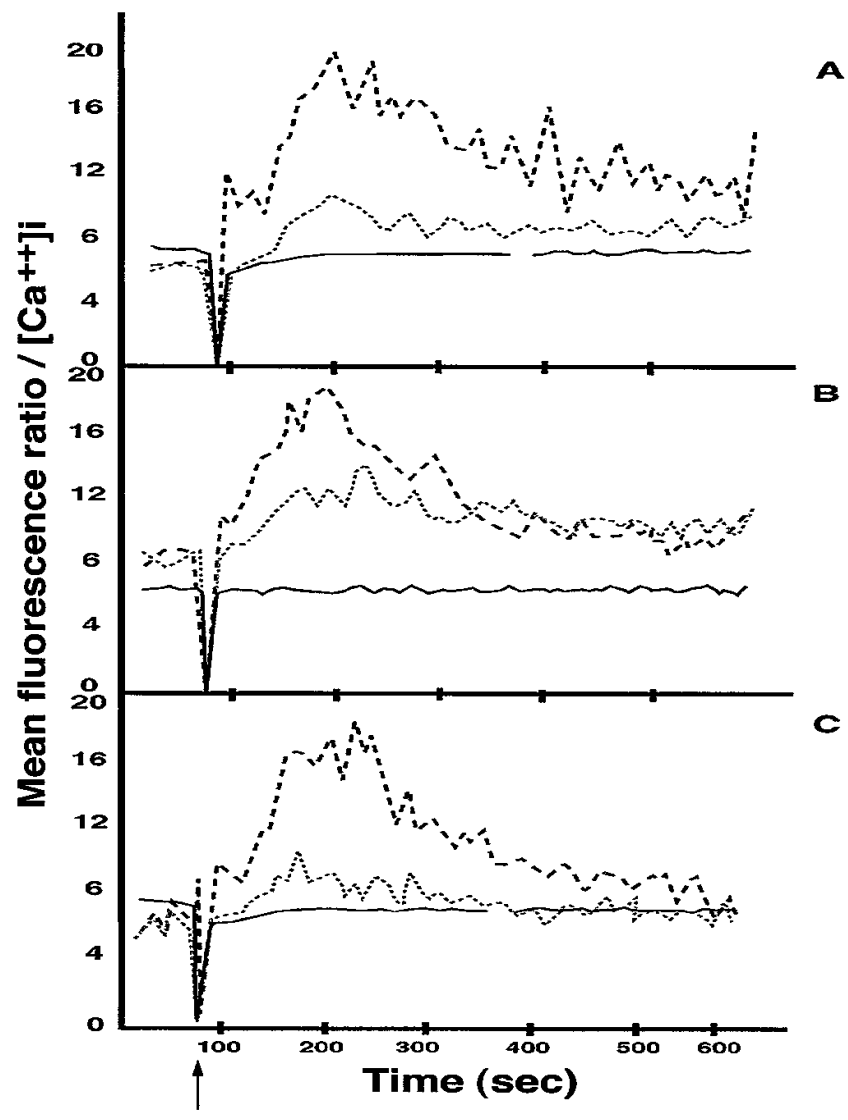

Figure 2. Representative anti-sIg-induced $\left[\mathrm{Ca}^{2+}\right]_{\mathrm{i}}$ responses in lupus patients and normal individuals. Five million PBMC enriched in B cells were loaded with the calcium-binding dye Indo-1 AM and fluorochrome-conjugated $\mathrm{mAbs}$ against non-B cell surface markers. Negatively selected B cells were stimulated with anti-BCR Abs $(40 \mu \mathrm{g} / \mathrm{ml}$ each) after $60 \mathrm{~s}$ of resting (arrow), and the response was recorded for a total of $10 \mathrm{~min}$. The $\left[\mathrm{Ca}^{2+}\right]_{\mathrm{i}}$ is proportional to the recorded mean fluorescence ratio $(381 / 525 \mathrm{~nm})$. In all three graphs, the highest curve (---) represents the response of lupus B cells, and the lowest (solid line) represents the response of B cells when medium only (instead of $\mathrm{Ab}$ ) was added (no response). The middle curve (....) in all three graphs shows the response of normal B cells. Lupus B cells display higher and more prolonged responses. Representative experiments with the use of: $(A)$ anti-sIgM; $(B)$ CBDA-4E5-4C7 anti-IgD mAb; and $(C)$ dIAG.2 anti-IgD mAb.

Although the peak $\left[\mathrm{Ca}^{2+}\right]_{\mathrm{i}}$ recordings were similar between the normal individuals and the disease controls $(10.41 \pm 0.53 \mathrm{vs}$ $10.65 \pm 0.59, P<0.78)$, the peak $\left[\mathrm{Ca}^{2+}\right]_{\mathrm{i}}$ responses were significantly higher $(14.60 \pm 0.90)$ in the SLE patient group. The peak response of lupus B cells was higher compared to the group of healthy volunteers $(P<0.002)$ and was also significantly higher in comparison with the group of patients with other autoimmune diseases $(P<0.005)$ (Fig. 3).

Any $\mathrm{sIg}$ isotype can participate in the formation of the BCR complex and the initiation of the B-cell signaling process, but the vast majority of B-cells carry BCRs comprising sIgM and $\operatorname{sigD}(44)$. To examine whether the abnormal $\left[\mathrm{Ca}^{2+}\right]_{i}$ response was restricted to sIgM-BCR, we used two different anti-sIgD murine mAbs to stimulate human $\mathrm{B}$ cells and recorded the changes in the levels of $\left[\mathrm{Ca}^{2+}\right]_{\mathrm{i}}$. The two murine mAbs, CBDA-4E5-4C7 and 8IAG.2, were used at concentra- 


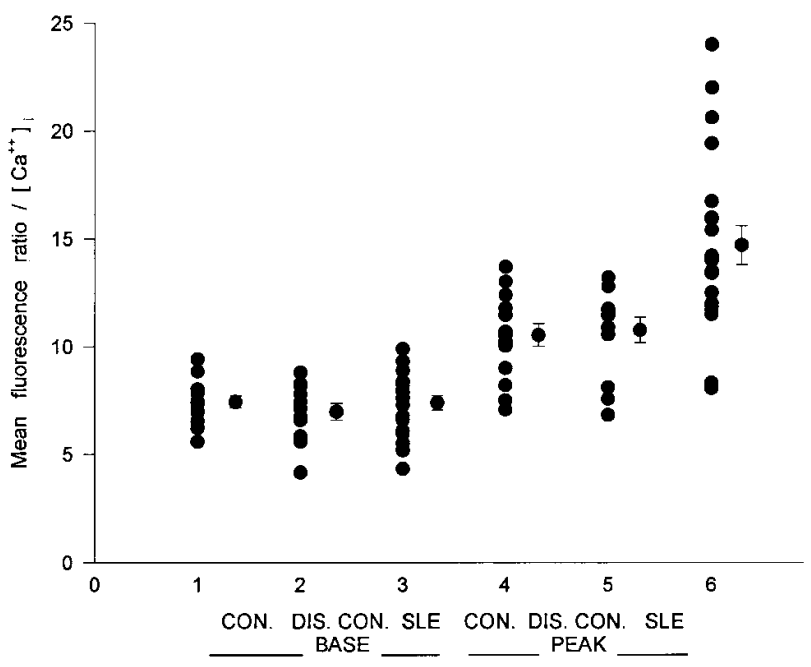

Figure 3. Anti-sIgM induced $\left[\mathrm{Ca}^{2+}\right]_{\mathrm{i}}$ responses in control, disease control, and SLE B cells. PBMC enriched in B cells were stimulated with $40 \mu \mathrm{g} / \mathrm{ml}$ of the $\mathrm{F}\left(\mathrm{ab}^{\prime}\right)_{2}$ fragment of a goat-anti-human $\mu \mathrm{Ab}$. The base line and the peak responses of intracellular free $\mathrm{Ca}^{2+}$ were recorded. While the base line values obtained were similar between the three groups, the peak $\left[\mathrm{Ca}^{2+}\right]_{\mathrm{i}}$ responses were significantly higher in the lupus patients group compared to the control $(P<0.002)$, as well as to the disease control group $(P<0.005)$. Bars represent the mean \pm SEM.

tions of $40 \mu \mathrm{g} / \mathrm{ml}$ each (Fig. $1, B$ and $C$ ). The CBDA-4E5-4C7 $\mathrm{mAb}$ induced significantly higher peak $\left[\mathrm{Ca}^{2+}\right]_{\mathrm{i}}$ responses in 12 of 14 SLE patients examined (Fig. 4) compared with 10 healthy individuals $(13.64 \pm 1.03$ vs $10.04 \pm 1.00, P<0.01)$. The SIAG.2 anti-sIgD mAb induced higher peak $\left[\mathrm{Ca}^{2+}\right]_{\mathrm{i}}$ responses in 9 out of the 14 SLE patients examined compared with 10 normal individuals (Fig. 5) but the difference did not reach sta-

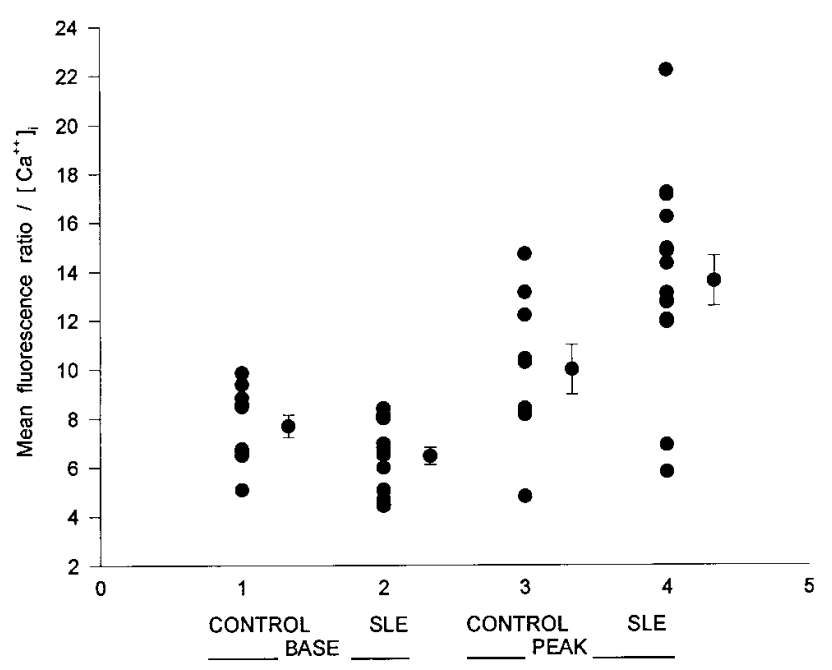

Figure 4. Anti-sIgD initiated $\left[\mathrm{Ca}^{2+}\right]_{\mathrm{i}}$ responses using the CBDA-4E5$4 \mathrm{C} 7$ murine anti-human $\mathrm{mAb}$. Base line values and peak $\left[\mathrm{Ca}^{2+}\right]_{\mathrm{i}}$ responses were recorded for B cells obtained from normal individuals and from lupus patients. Stimulation was performed with $40 \mu \mathrm{g} / \mathrm{ml}$ of the Ab. Significantly higher peak free intracellular $\mathrm{Ca}^{2+}$ responses were observed for the SLE patients group $(P<0.01)$. Bars represent the mean \pm SEM.

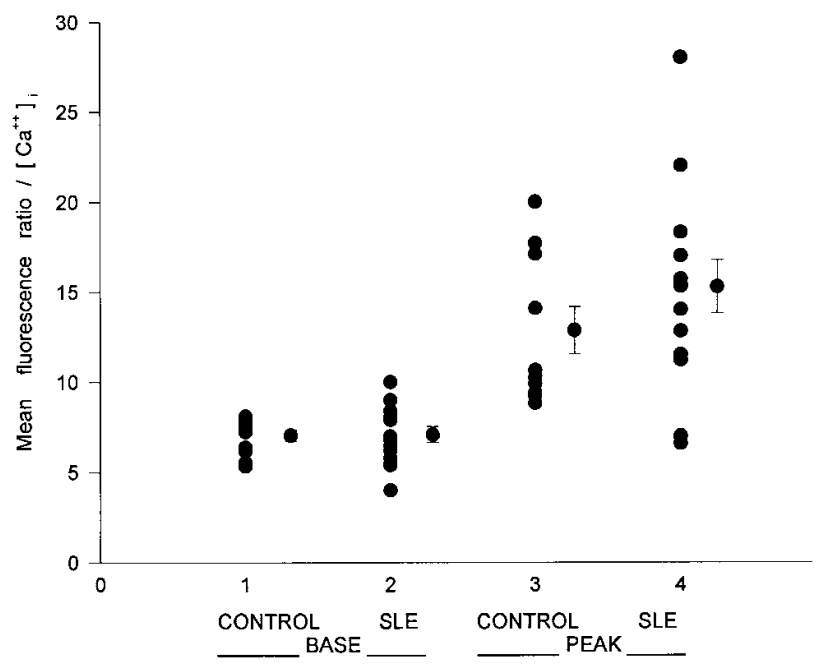

Figure 5. Anti-sIgD initiated $\left[\mathrm{Ca}^{2+}\right]_{\mathrm{i}}$ responses using the $\delta \mathrm{IAG} .2 \mathrm{mu}-$ rine anti-human $\mathrm{mAb}$. Equal numbers of SLE and healthy individuals' B cells were stimulated with $40 \mu \mathrm{g} / \mathrm{ml}$ of this mAb. Lupus B cells responded higher than the controls but the difference did not reach statistical significance $(P<0.07)$. Bars represent the mean \pm SEM.

tistical significance $(P<0.07)$. Representative experiments with the use of these two anti-IgD mAbs are shown in Figs. 2, $B$ and $C$. The representative curves of Fig. 2 also show that the $\left[\mathrm{Ca}^{2+}\right]_{\mathrm{i}}$ responses were also prolonged in lupus B cells. This was true for all those SLE patients which displayed higher $\mathrm{Ca}^{2+}$ fluxes than their respective controls regardless of the stimulatory Ab used.

These experiments demonstrate clearly that fresh B cells from patients with SLE display increased BCR-mediated $\left[\mathrm{Ca}^{2+}\right]_{\mathrm{i}}$ responses that are not restricted to only one sIg isotype. Of importance is the fact that increased $\left[\mathrm{Ca}^{2+}\right]_{\mathrm{i}}$ responses were observed only in lupus patients.

sIgM-initiated $\left[\mathrm{Ca}^{2+}\right]_{i}$ changes due to release from intracellular stores are higher in B cells from SLE patients. Changes in the concentration of $\left[\mathrm{Ca}^{2+}\right]_{\mathrm{i}}$ induced upon BCR stimulation reflect release of $\mathrm{Ca}^{2+}$ from intracellular stores and influx of $\mathrm{Ca}^{2+}$ from the extracellular space (28). The $\mathrm{InsP}_{3}$ that is produced after ligation of the BCR complex induces the release of $\mathrm{Ca}^{2+}$ from the intracellular stores. To examine this specific component of the calcium response, we used EGTA to chelate the extracellular $\mathrm{Ca}^{2+}$. The BCR-mediated changes in $\left[\mathrm{Ca}^{2+}\right]_{i}$ would thus reflect the component of the response that is due to the intracellularly stored $\mathrm{Ca}^{2+}$ only. Levels of the intracellularly stored $\mathrm{Ca}^{2+}$ can be affected by changes in the extracellular concentration of the ion. Therefore, we used 5 mM EGTA immediately before the beginning of the $\mathrm{Ca}^{2+}$ measurement. The anti-sIgM-induced peak $\left[\mathrm{Ca}^{2+}\right]_{\mathrm{i}}$ response in the presence of $5 \mathrm{mM}$ EGTA is significantly higher in B cells from SLE patients compared to the response of the normal individuals as shown in Table I. These experiments indicate that increased release of $\mathrm{Ca}^{2+}$ from its intracellular stores contributes significantly to the observed augmentation of BCR-mediated $\left[\mathrm{Ca}^{2+}\right]_{i}$ response in lupus B cells.

Anti-sIgM-induced InsP production. The release of intracellularly stored $\mathrm{Ca}^{2+}$ from the endoplasmic reticulum to the cytoplasm occurs upon binding of the second messenger InsP to its receptor $\left(\mathrm{InsP}_{3} \mathrm{R}\right)$. To investigate whether the increased 
Table I. Contribution of Intracellularly Stored Calcium to the $\left[\mathrm{Ca}^{2+}\right]_{i}$ Response as Measured by EGTA Treatment of Normal and Lupus B Cells*

\begin{tabular}{lccc}
\hline & \multicolumn{3}{c}{ Peak/baseline $\left[\mathrm{Ca}^{2+}\right]_{\mathrm{i}}$ ratio } \\
\cline { 2 - 4 } EGTA treatment & SLE $(n)$ & Control $(n)$ & $P$ value \\
\hline No & $1.97 \pm 0.11(5)$ & $1.27 \pm 0.05(3)$ & 0.004 \\
Yes & $1.59 \pm 0.12(5)$ & $1.13 \pm 0.04(3)$ & 0.031
\end{tabular}

*Values obtained before and after the addition of 5 mM EGTA refer to the same SLE patients or normal individuals. The ratio of the peak over the base fluorescence values for $\left[\mathrm{Ca}^{2+}\right]_{\mathrm{i}}$ was estimated, and the mean \pm SEM are represented here for each group. ${ }^{\ddagger}$ Values of $P<0.05$ were considered as statistically significant.

$\left[\mathrm{Ca}^{2+}\right]_{\mathrm{i}}$ response in lupus B cells after crosslinking of the $\mathrm{sIgM}$ is due to increased $\mathrm{InsP}_{3}$ production, we incubated PBMC enriched in $\mathrm{B}$ cells with tritiated myoinositol, stimulated them with $20 \mu \mathrm{g}$ of the $\mathrm{F}\left(\mathrm{ab}^{\prime}\right)_{2}$ fragment of a goat-anti-human $\mu \mathrm{Ab}$, and measured the inositol phosphate metabolites using anionexchange chromatography at three time-points $(0,5$, and 10
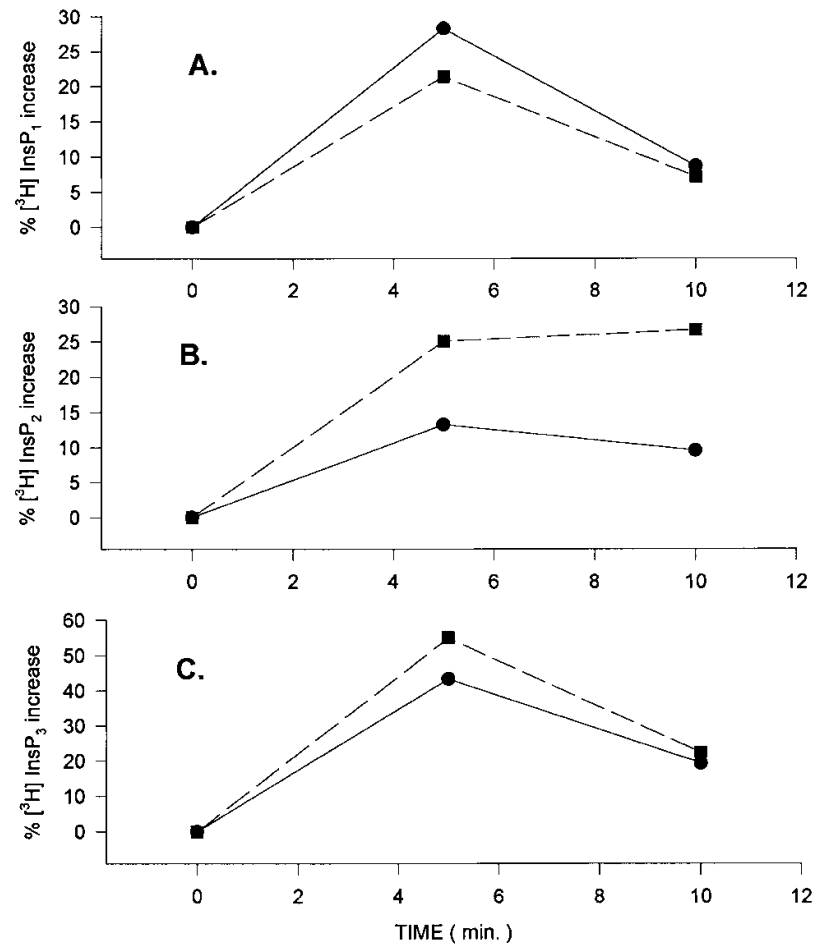

Figure 6. Anti-sIgM initiated production of inositol phosphate metabolites in B cells from a lupus patient ( $\square$ ) and a control ( - ) individual. (One representative experiment out of four with similar results). Three million PBMC greatly enriched in B lymphocytes were incubated with tritiated myoinositol, stimulated with $20 \mu \mathrm{g}$ of the $\mathrm{F}\left(\mathrm{ab}^{\prime}\right)_{2}$ fragment of a goat-anti-human $\mu \mathrm{Ab}$ for 0,5 , and 10 min and lysed. The tritiated inositol phosphate metabolites $\left[{ }^{3} \mathrm{H}\right] \mathrm{InsP}_{1}$ $(A),\left[{ }^{3} \mathrm{H}\right] \operatorname{InsP}_{2}(B)$, and the $\left[{ }^{3} \mathrm{H}\right] \operatorname{InsP}_{3}(C)$, were resolved by anion exchange chromatography. Results are expressed as the percentage of increase in the levels of each metabolite over the levels obtained in cells stimulated with medium alone for the same time period. Lupus samples produced slightly (but not significantly) higher amounts of $\mathrm{InsP}_{2}$ and more importantly $\mathrm{InsP}_{3}$. min after the addition of anti-sIgM Ab). Fig. 6 shows one representative experiment of four. The anti-sIgM-induced levels of inositol phosphate metabolites were always slightly higher than the levels that were observed in normal cells, but the difference did not reach statistical significance. These experiments show that the observed increased BCR-mediated $\left[\mathrm{Ca}^{2+}\right]_{\mathrm{i}}$ responses in lupus B cells do not appear to be due to increased $\mathrm{BCR}$-induced $\mathrm{InsP}_{3}$ production.

The anti-sIgM-induced phosphorylation of protein tyrosine residues is increased in lupus $B$ cells. Perhaps the earliest event after the BCR ligation is the activation of a cascade of protein tyrosine kinases, which phosphorylate various proteins on tyrosine residues. Several quite important cellular functions are executed and regulated by the action of these kinases, the calcium response being one of them. As has been shown in several cell types including B cells, modulations in the action of the "pre-Ca ${ }^{2+}$ " kinases may lead to altered calcium responses. Over or underexpression of members of this pathway in immune cells results in increased or decreased activity of the kinases and may modify the amount of $\mathrm{Ca}^{2+}$ mobilization (45$48)$. Since we observed increased BCR-initiated $\left[\mathrm{Ca}^{2+}\right]_{i}$ values in lupus $\mathrm{B}$ cells we conducted experiments to determine whether this phenomenon was correlated with altered BCRmediated overall "pre- $\mathrm{Ca}^{2+}$ " protein tyrosine kinase (PTK) activity.

An equal number of PBMC enriched in B cells was stimulated with $20 \mu \mathrm{g}$ of the $\mathrm{F}\left(\mathrm{ab}^{\prime}\right)_{2}$ fragment of a goat anti-human $\mu \mathrm{Ab}$ for $60 \mathrm{~s}$, a time that has been known to be required for maximal anti-sIgM-induced PTK activity (49). After lysing the cells, an equal amount of protein was electrophoretically separated on gels, transferred on membranes and blotted with an anti-phosphotyrosine-HRPO-conjugated $\mathrm{mAb}$. Results show (Fig. 7), that in two out of three SLE patients examined, the overall degree of tyrosine phosphorylation was obviously increased. Although we did not notice the appearance of new

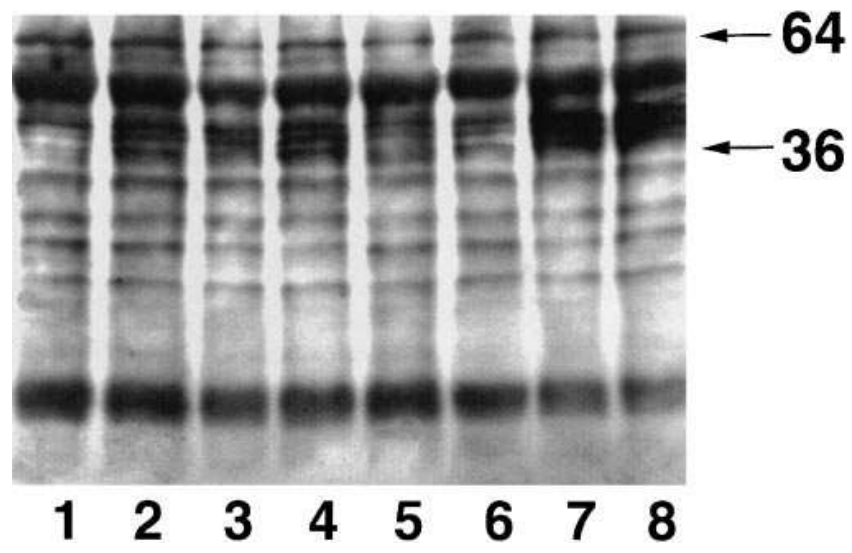

Figure 7. Anti-sIgM-induced tyrosine phosphorylation of lupus and control B cells. Five million normal or SLE B cells were stimulated for $60 \mathrm{~s}$ using $40 \mu \mathrm{g} / \mathrm{ml}$ of anti-sIgM. Protein $(30 \mu \mathrm{g})$ from each lysate was electrophoretically separated on SDS $/ 10 \%$ polyacrylamide gels, transferred on nitrocellulose membranes and immunoblotted with an anti-phosphotyrosine mAb. Lupus B cells (lanes 6-8) show increased tyrosine phosphorylation compared to control B lymphocytes (lane 5 ) of at least four bands between the $64-$ and $36-\mathrm{kD}$ mol wt standards. Fresh unstimulated normal (lane 1) and lupus B cells (lane 2), and normal cells (lane 3), as well as SLE cells (lane 4) incubated with medium alone are also shown. 
Table II. Correlation between Disease Activity, Treatment Regimes, and $\left[\mathrm{Ca}^{2+}\right]_{i}$ Responses in Lupus B Cells*

\begin{tabular}{llll}
\hline \multirow{2}{*}{\multicolumn{1}{c}{ Parameter }} & \multicolumn{3}{c}{ Peak/baseline $\left[\mathrm{Ca}^{2+}\right]_{\mathrm{i}}$ ratio } \\
\cline { 2 - 4 } & \multicolumn{1}{c}{ Present $(n)$} & Absent $(n)$ & $P$ value \\
\hline SLEDAI score $\geq 4$ & $2.05 \pm 0.06(15)$ & $2.04 \pm 0.22(6)$ & 0.97 \\
Prednisone & $2.04 \pm 0.16(15)$ & $2.06 \pm 0.21(6)$ & 0.94 \\
Hydroxychloroquine & $1.93 \pm 0.15(13)$ & $2.22 \pm 0.22(8)$ & 0.29 \\
Cytotoxics & $2.51 \pm 0.46(4)$ & $1.93 \pm 0.11(17)$ & 0.08 \\
SLE & $2.04 \pm 0.13(21)^{\ddagger}$ & $1.43 \pm 0.06(17)^{\S}$ & $0.001^{\|}$
\end{tabular}

*Disease activity and form of treatment were determined at the time of the study for each patient. The ratio of the peak over the base fluorescence values for $\left[\mathrm{Ca}^{2+}\right]_{\mathrm{i}}$ was estimated, and the mean \pm SEM are represented here for each subgroup. ${ }^{\ddagger}$ value for the whole SLE patient group; ${ }^{\S}$ value for the whole group of healthy individuals; $"$ statistically significant $(P<0.05)$.

bands the intensity of at least four of them, located between the 64- and the $36-\mathrm{kD}$ mol wt standards, was obviously enhanced. Moreover, the intensity of these bands (determined densitometrically) was directly proportional to the magnitude of the $\mathrm{Ca}^{2+}$ response for each individual SLE patient studied. The activity/availability therefore of the PTKs assessed by the overall degree of tyrosine phosphorylations was positively correlated with the volume of the $\left[\mathrm{Ca}^{2+}\right]_{\mathrm{i}}$ response in lupus $\mathrm{B}$ cells.

$\left[\mathrm{Ca}^{2+}\right]_{i}$ responses in SLE B cells do not correlate with disease activity and treatment status. At the time of the study, an SLEDAI score was determined for each patient and treatment, if any, consisting of prednisone, hydroxychloroquine, and cytotoxic drugs (azathioprine, cyclophosphamide, methotrexate) was also recorded. Patients were classified as having active disease when the SLEDAI score was four or higher. Table II shows that there were no significant differences among patients with active or inactive disease at the time of the study. Moreover, treatment status did not affect the recorded responses. The lupus group had significantly higher peak/baseline ratios when compared with the control group $(P=0.001)$ and to the disease-control group $(P=0.01)$. The lack of any correlation between $\mathrm{Ca}^{2+}$ responses and the activity of the disease suggests that the cell signaling abnormalities reported herein may be of pathogenetic importance.

\section{Discussion}

We conducted the present study to investigate the possible aberrations in the early events of the signal transduction pathway in lupus B cells. Our purpose was to test the hypothesis that B cells in SLE are not innocent bystanders of an altered T cell activity but exhibit inherent biochemical defects. We used antisIgM and anti-sIgD Abs to stimulate fresh, unmanipulated B cells from lupus, disease controls, and normal individuals, and evaluated the $\left[\mathrm{Ca}^{2+}\right]_{i}$ response, the tyrosine phosphorylation pattern and the inositol phosphate metabolite production. We found that lupus, but not disease control, B cells exhibit significantly higher responses regardless of the crosslinking anti-sIg $\mathrm{Ab}$ that did not correlate with disease activity or treatment status.
Our findings clearly demonstrated that the anti-sIgMinduced peak $\left[\mathrm{Ca}^{2+}\right]_{\mathrm{i}}$ responses were significantly higher in lupus B cells compared with responses of B cells from the normal group, although their resting $\left[\mathrm{Ca}^{2+}\right]_{i}$ were similar. Moreover, the peak $\left[\mathrm{Ca}^{2+}\right]_{\mathrm{i}}$ values recorded for lupus B cells were also significantly higher than those observed for B cells obtained from patients with other systemic autoimmune rheumatic diseases. This latter group of patients had baseline as well as peak $\left[\mathrm{Ca}^{2+}\right]_{\mathrm{i}}$ responses similar to the normal group. Our results suggest the existence of an SLE-specific abnormality in the signaling events in lupus B cells.

The vast majority of $\mathrm{B}$ cells are $\operatorname{sgM}$ and $\operatorname{sigD}$ positive. No differences in the expression of these two surface immunoglobulins were found between lupus and normal B cells (data not shown). To test whether or not our results were sIgM specific, we evaluated the anti-sIgD-mediated $\mathrm{Ca}^{2+}$ responses using two different murine anti-IgD mAbs. The anti-sIgD-induced responses were again significantly enhanced for one of the two mAbs used, while the other produced higher but not statistically significant elevations. The anti-sIgD recorded $\mathrm{Ca}^{2+}$ fluxes were shorter in duration than the responses to anti-sIgM, in accordance with previously described data (50). These findings indicate that SLE B cells exhibit a disease-specific abnormality in the BCR-mediated $\left[\mathrm{Ca}^{2+}\right]_{\mathrm{i}}$ responses.

The $\mathrm{Ca}^{2+}$ response to ligation of the $\mathrm{BCR}$ results from the release of stored calcium from the internal stores to the cytoplasm initially followed by influx of the ion from the extracellular space. By adding the chelating agent EDTA to the medium immediately before the recording, we were able to study the release of the ion from the endoplasmic reticulum. These experiments yielded an augmented $\left[\mathrm{Ca}^{2+}\right]_{i}$ response in lupus $\mathrm{B}$ cells, suggesting that increased release of stored $\mathrm{Ca}^{2+}$ contributes to the initially recorded higher peak $\left[\mathrm{Ca}^{2+}\right] \mathrm{i}$ responses in $B$ cells from patients with SLE.

The BCR complex is a hetero-oligomer, consisting of the surface immunoglobulin molecule and the $\operatorname{Ig}-\alpha / \beta$ heterodimer(s) $(51,52)$. The latter two molecules are responsible for the signal-transducing properties of the antigen receptor (43). The signaling motif ITAM (Ig [superfamily] tyrosine-based activation motif) is present in the cytoplasmic tails of both $\mathrm{Ig}-\alpha$ and Ig- $\beta$ (54). ITAM has been shown to be sufficient and necessary to carry out signaling functions, including PTK activation, protein tyrosine phosphorylation, and $\mathrm{Ca}^{2+}$ mobilization (22). PTKs involved include the $s r c$-family members $\mathrm{p} 55^{\mathrm{blk}}$, p59 $9^{\mathrm{fyn}}$, and $\mathrm{p} 53 / 56^{\mathrm{lyn}}$ and the cytoplasmic PTK p72 ${ }^{\text {syk }}$ (55-57). After sIg ligation $\mathrm{p} 72^{\mathrm{syk}}$ becomes autophosphorylated first $(58,59)$, which leads to binding of the $s r c$-family kinases through their SH-2 domains, derepressing tyrosyl kinase activation (60). This, in turn, leads to tyrosyl phosphorylation of $\mathrm{Ig}-\alpha$ and $\mathrm{Ig}-\beta$ ITAMs (61), with resultant activation, reorientation and recruitment of additional $s r c$-family kinase molecules (62). The activated $s r c$-family kinases regulate several cascades including the activation of PLC $\gamma 2$, of mitogen-activated protein kinase (MAPK), of GTPase-activating protein (GAP), of the p21 $1^{\text {ras }}$ pathway, and of phosphoinositide 3-kinase (PI 3-K) (63-65).

Ligation of either $\operatorname{SIgM}$ or $\operatorname{sgD}$ results in the activation of the same PTKs, which in turn phosphorylate the same substrates (66-68) and consequently lead to the $\mathrm{Ca}^{2+}$ mobilization response (69). Both "precalcium" segments are qualitatively, but not quantitatively, identical, since their regulatory mechanisms might differ (49). The "postcalcium" events might be quite dissimilar as well $(70,71)$. 
Therefore, BCR ligation leads to immediate activation of several PTKs and phosphorylation of substrates on tyrosine residues. To investigate the relative amount of early tyrosine phosphorylation in B cells from SLE patients, we immunoblotted lysates from SLE and control B cells activated with antisIgM, with an antiphosphotyrosine $\mathrm{mAb}$. There were no differences in the amount of tyrosine phosphorylated substrates between lupus and normal B cells in the resting state. After 60 $s$ of stimulation with the same $F\left(a b^{\prime}\right)_{2}$ anti- $\mu$ fragment we observed markedly enhanced tyrosine phosphorylation of several protein bands from lupus samples, indicating increased PTK activation in lupus B cells compared with normal controls. Even though the cell populations used did not consist of pure B cells ( $>90 \%$ B cells determined flow cytometrically), the stimulus that we used is B cell specific because only B cells bear sIgM. Thus, any resultant increase in tyrosine phosphorylation of substrates, cannot be attributed to any other cell subpopulation.

Interestingly, the amount of inositol phosphate metabolites InsP $\mathrm{P}_{1}, \mathrm{InsP}_{2}$, and, more importantly, of $\mathrm{InsP}_{3}$ produced after sIgM stimulation, were only slightly, but not statistically significantly, higher in lupus than in normal cells. One explanation for this discrepancy between increased $\mathrm{Ca}^{2+}$ responses and normal $\mathrm{InsP}_{3}$ production may be an increased density of $\mathrm{InsP}_{3} \mathrm{R}$ on the Ca stores in the lupus cells, as has been described in some cell types $(72,73)$. Alternatively, increased Ins $\mathrm{P}_{3} \mathrm{R}$ binding resulting in enhanced release of calcium may be present. The sensitivity of the $\operatorname{InsP}_{3} \mathrm{R}$ is regulated by $\operatorname{InsP}_{3}$ itself, by $\mathrm{Ca}^{2+}$ and by PTK-mediated phosphorylation (74). Interestingly, antigen receptor-mediated and Fyn-dependent phosphorylation of the $\operatorname{Ins}_{3} \mathrm{R}$ caused higher responses in $\mathrm{T}$ cells and also increased the inhibitory threshold of rising $\left[\mathrm{Ca}^{2+}\right]_{\mathrm{i}}$ on the receptor. Increased availability or activity, therefore, of certain PTKs influences the sensitivity of the calcium channels and promotes increased responses upon antigen receptor stimulation. To date, similar studies have not been performed on normal or lupus $\mathrm{B}$ cells. Finally, an $\mathrm{InsP}_{3}$-independent $\mathrm{Ca}^{2+}$ mobilizing mechanism may be operative in SLE $\mathrm{B}$ cells. Evidence that such a mechanism might exist is provided from experiments with B cells and other cell types (4547). This might implicate abnormal expression of certain protein tyrosine kinases in SLE B cells. Such evidence has been provided by the recent finding of overexpression of the $\mathrm{p} 59^{\text {fyn }}$ in $\mathrm{T}$ cells from the $l p r / l p r$ murine model of SLE and from transfected cells overexpressing p59 $9^{\mathrm{fyn}}(47,48)$. At present, no data exist for B cells.

Work from this laboratory has recently shown that a similar abnormality in the antigen receptor-mediated $\mathrm{Ca}^{2+}$ response is associated with normal $\mathrm{InsP}_{3}$ production in lupus $\mathrm{T}$ cells as well (41). The tyrosine phosphorylation pattern was not addressed. It may be, therefore, appropriate to assume that lupus $\mathrm{T}$ and $\mathrm{B}$ cells display similar cell signaling-associated biochemical abnormalities. Why do lupus B and T cells respond in an altered manner to stimuli that closely mimic physiologic stimuli? The recent description by Kammer et al. (42) that lupus $\mathrm{T}$ cells have abnormally low levels of the cAMPdependent-PKA isozyme I activity, may offer some explanation. The intracellular levels of cAMP and the activity of this enzyme can influence the $\mathrm{Ca}^{2+}$ response after antigen receptor ligation in T cells (75-77). Since increased cAMP and PKA activity can down regulate the calcium response, our observation of heightened $\left[\mathrm{Ca}^{2+}\right]_{i}$ values might be explained by a dimin- ished function of the cAMP/PKA system. Recently, a cAMPsensitive $\mathrm{K}^{+}$channel was also described on the plasma membrane operating in activated cells only. An increase in intracellular cAMP acting on this channel influences adversely the magnitude of the free $\mathrm{Ca}^{2+}$ response (78). Increased $\left[\mathrm{Ca}^{2+}\right]_{\mathrm{i}}$ responses as the ones we describe could be then attributed to decreased intracellular cAMP.

Provided that the same PKA enzymatic defect exists in SLE B cells, we hypothesize that the defective inhibitory cAMP/PKA-I pathway might contribute to the augmented $\left[\mathrm{Ca}^{2+}\right]_{\mathrm{i}}$ responses of the lupus immune cells. Evidence that further supports this hypothesis was provided from the study of a single patient, (included in our SLE patients group), who had unusually normal cAMP-dependent PKA-I activity in her T cells. As could be predicted from the above hypothesis, her BCR-induced $\left[\mathrm{Ca}^{2+}\right]_{\mathrm{i}}$ response was normal. More work is necessary though, $(a)$ to establish that this enzymatic defect also characterizes lupus B cells, $(b)$ to examine whether other patients as the one mentioned above respond in the same way and $(c)$ to determine the availability and/or activity of each one of the early protein kinase systems.

The function of intracellular $\mathrm{Ca}^{2+}$ underlines the physiologic importance of our findings. Numerous intracellular enzymes and a spectrum of diverse and even quite opposite cellular functions are $\mathrm{Ca}^{2+}$ regulated (22, 27, 79-81). Indeed, abnormalities of some of these functions have been described in the human and the murine lupus (82-85).

In this study we have demonstrated that lupus B cells exhibit abnormal early signal transduction events. Because these abnormalities were not related to disease activity and because they were limited to lupus B cells, we conclude that they may be due to intrinsic defect(s) of the B cell, which may contribute to the pathogenesis of the disease.

\section{Acknowledgments}

We are indebted to Dr. Fred Finkelman for valuable comments at the beginning of the study and his generous supply of anti-IgD mAbs. The expert help of Mr. Lloyd Billups with the flow cytometer is appreciated.

Dr. Liossis was supported in part by a scholarship from the Hellenic Society of Rheumatology. This study was supported by work unit 9297 from the Department of Clinical Investigation, Walter Reed Army Medical Center. The opinions and assertions contained herein are the private views of the authors and are not to be construed as official or reflecting the views of the Department of the Army or the Department of Defense.

\section{References}

1. Tsokos, G.C. 1992. Overview of cellular immune function in systemic lupus erythematosus. In Systemic Lupus Erythematosus. R.G. Lahita, editor. Churchill Livingstone, New York. 15-50.

2. Theofilopoulos, A.N., G.J. Prud'Homme, and F.J. Dixon. 1985. Autoimmune aspects of systemic lupus erythematosus. Concepts Immunopathol. 1:190218.

3. Ginsburg, W.W., F.D. Finkelman, and P.E. Lipsky. 1979. Circulating and pokeweed-mitogen-induced immunoglobulin-secreting cells in systemic lupus erythematosus. Clin. Exp. Immunol. 35:76-88.

4. Theofilopoulos, A.N. 1992. Murine models of lupus. In Systemic Lupus Erythematosus. R.G.Lahita, editor. Churchill Livingstone, New York. 121-194.

5. Kofler, D., V. Agnello, R. Thoburn, and H.G. Kunkel. 1971. Systemic lupus erythematosus: prototype of immune complex nephritis in man. J. Exp. Med. 134:169S.

6. Raz, E., M. Brezis, E. Rosenmann, and D. Eilat. 1989. Anti-DNA antibodies bind directly to renal antigens and induce kidney dysfunction in the isolated perfused rat kidney. J. Immunol. 142:3076-3082. 
7. Morimoto, C., A. Steinberg, N. Letvin, M. Hagan, T. Takeuchi, J. Daley, H. Levine, and S. Schlossman. 1987. A defect of immunoregulatory T cell subsets in systemic lupus erythematosus patients identified with anti-2 $\mathrm{H} 4$ antibody. J. Clin. Invest. 79:762-768.

8. Inghirami, G., J. Simon, J.E. Balow, and G.C. Tsokos. 1988. Activated T lymphocytes in the peripheral blood of patients with systemic lupus erythematosus induce B cells to produce immunoglobulin. Clin. Exp. Rheumatol. 6:269276.

9. Shivakumar, S., G.C. Tsokos, and S.K. Datta. 1989. T-cell receptor alpha/ beta expressing double-negative $\left(\mathrm{CD}^{-} / \mathrm{CD} 8^{-}\right)$and $\mathrm{CD}^{+} \mathrm{T}$ helper cells in humans augment the production of pathogenic anti-DNA autoantibodies associated with lupus nephritis. J. Immunol. 143:103-112.

10. Salata, M., J. Golbus, and B.C. Richardson. 1988. Diminished response to an inhibitory signal in lymphocytes from patients with systemic lupus erythematosus. Clin. Exp. Immunol. 71:439-444.

11. Flescher, E., D. Fossum, A. Ballester, A. Maizel, S. Sharma, and N. Talal. 1990. Characterization of B cell growth in systemic lupus erythematosus: effects of recombinant 12-Kda B cell growth factor, interleukin-4 and transforming growth factor- $\beta$. Eur. J. Immunol. 20:2425-2430.

12. Golbus, J., M. Salata, J.Greenwood, J. Hudson, and B.C. Richardson. 1988. Increased immunoglobulin response to gamma-interferon by lymphocytes from patients with systemic lupus erythematosus. Clin. Immunol. Immunopathol. 46:129-140.

13. Llorente, L., W. Zou, Y. Levy, Y. Richard-Patin, J. Wijdenes, J. Alcover-Varela, B. Morel-Fourrier, J. Brouet, D. Alarcon-Segovia, P. Galanaud, and D. Emilie. 1995. Role of interleukin 10 in B cell overactivity and autoantibody production of human systemic lupus erythematosus. J. Exp. Med. 181: 839-844.

14. Tsokos, G.C., and J.E. Balow. 1981. Spontaneous and pokeweed mitogen-induced plaque-forming cells in systemic lupus erythematosus. Clin. Immunol. Immunopathol. 21:172-183.

15. Tsokos, G.C., I.T. Magrath, and J.E. Balow. 1983. Epstein-Barr virus induces normal $\mathrm{B}$ cell responses but defective suppressor $\mathrm{T}$ cell responses in patients with systemic lupus erythematosus. J. Immunol. 131:1797-1801.

16. Dong, X., K.J. Hamilton, M. Satoh, J. Wang, and W.H. Reeves. 1994. Initiation of autoimmunity to the p53 tumor suppressor protein by complexes of p53 and SV40 large T antigen. J. Exp. Med. 179:1243-1252.

17. Reininger, L., T. Radaszkiewitz, M. Kosco, F. Melchers and A.G. Rolnick. 1992. Development of autoimmune disease in SCID mice populated with long-term in vitro proliferating (NZB X NZW) F1 pre-B cells. J. Exp. Med. 176:1343-1353

18. Murakami, M., H. Yoshioka, T. Shirai, T. Tsubata, and T. Honjo. 1995. Prevention of autoimmune symptoms in autoimmune-prone mice by elimination of B-1 cells. Int. Immunol. 7:877-882.

19. Wen, L., S. Roberts, F.S. Wong, C. Mallick, R.C. Findly, Q. Peng, J.E. Craft, M.J. Owen, and A.C. Hayday. 1994. Immunoglobulin synthesis and generalized autoimmunity in mice congenitally deficient in alpha beta $(+) \mathrm{T}$ cells. Nature (Lond.). 369:654-658.

20. Rosen, A., L. Casciola-Rosen, and J. Ahearn. 1995. Novel packages of viral and self-antigens are generated during apoptosis. J. Exp. Med. 181:15571561.

21. Cambier, J.C., C.M. Pleiman, and M.R. Clark. 1994. Signal transduction by the B cell receptor and its coreceptors. Annu. Rev. Immunol. 12:457-486.

22. Weiss, A., and D.R. Littman. 1994. Signal transduction by lymphocyte antigen receptors. Cell. 76:263-274.

23. Coggeshall, K.M., J.C. McHugh, and A. Altman. 1992. Predominant expression and activation-induced tyrosine phosphorylation of phospholipase C- $\gamma 2$ in B lymphocytes. Proc. Natl. Acad. Sci. USA. 89:5660-5664.

24. Nishizuka, Y. 1992. Intracellular signaling by hydrolysis of phospholipids and activation of protein kinase C. Science (Wash. DC). 258:607-614.

25. Coggeshall, K.M., and J.C. Cambier. 1984. B cell activation. VIII. Membrane immunoglobulins transduce signals via activation of phosphatidylinositol hydrolysis. J. Immunol. 133:3382-3386.

26. Bijsterbosch, M.K., and G.G.B. Klaus. 1985. Crosslinking of surface immunoglobulin and $\mathrm{Fc}$ receptors on B lymphocytes inhibits stimulation of inositol phosphate breakdown via the antigen receptors. J. Exp. Med. 162:18251827.

27. Nishizuka, Y. 1992. Intracellular signaling by hydrolysis of phospholipids and activation of protein kinase C. Science (Wash. DC). 258:607-614.

28. Berridge, M.J. 1993. Inositol trisphosphate and calcium signaling. $\mathrm{Na}$ ture (Lond.). 361:315-325.

29. Boyle, W.M., T. Smeal, L.H.K. Defize, P. Angel, J.R. Woodgett, M. Karin, and T. Hunter. 1991. Activation of protein kinase C decreases phosphorylation of c-Jun at sites that negatively regulate its DNA-binding activity. Cell. 64:573-584.

30. Fisher, C.L., J. Ghysdael, and J.C. Cambier. 1991. Ligation of membrane immunoglobulin leads to calcium mediated phosphorylation of the protooncogene product, Ets-1. J. Immunol. 146:1743-1749.

31. Girard, S., and D. Clapham. 1993. Acceleration of intracellular calcium waves in Xenopus oocytes by calcium influx. Science (Wash. DC). 260:229-232.

32. Gelfand, E.W., R.K. Cheung, S. Grinstein, and G.B. Mills. 1986. Characterization of the role for calcium influx in mitogen-induced triggering of hu- man T cells: identification of calcium-dependent and calcium-independent signals. Eur. J. Immunol. 16:907-912.

33. Lechleiter, J.D., and D. Clapham. 1992. Molecular mechanisms of intracellular calcium excitability in X. laervis oocytes. Cell. 69:283-294.

34. Gardner, P. 1989. Calcium and T lymphocyte activation. Cell. 59:15-20.

35. Oshimi, Y., and S. Miyazaki. 1995. Fas antigen-mediated DNA fragmentation and apoptotic morphologic changes are regulated by elevated cytosolic $\mathrm{Ca}^{++}$level. J. Immunol. 154:599-609.

36. Tan, E.M., A.S. Cohen, J.F. Fries, A.T. Masi, D.J. McShane, N.F. Rothfield, J.G. Schaller, N. Talal, and R.J. Winchester. 1982. The 1982 revised criteria for the classification of systemic lupus erythematosus. Arthritis Rheum. 25: 1271-1277.

37. Bombardier, C., D.D. Gladman, M.B. Urowitz, D. Caron, and C.H. Chang. 1992. Derivation of the SLEDAI. A disease activity index for lupus patients. Arthritis Rheum. 35:630-640.

38. Falkoff, R.M., M. Peters, and A.S. Fauci. 1982. T cell enrichment and depletion of human peripheral blood mononuclear cell preparations. Unexpected findings in the study of the functional activities of the separated populations. J. Immunol. Methods. 50:3999-4049.

39. Rabinovitch, M., and M.J. DeStefano. 1973. Macrophage spreading in vitro. Exp. Cell Res. 77:323-334.

40. Rabinovitch, P.S., C.H. June, A. Grossmann, and J.A. Ledbetter. 1986. Heterogeneity among $\mathrm{T}$ cells in intracellular free calcium responses after mitogen stimulation with PHA or anti-CD3: simultaneous use of indo-1 and immunofluorescence with flow cytometry. J. Immunol. 137:952-961.

41. Vassilopoulos, D., B. Kovacs, and G.C. Tsokos. 1995. TCR/CD3 complex-mediated signal transduction pathway in $\mathrm{T}$ cells and $\mathrm{T}$ cell lines from patients with systemic lupus erythematosus. J. Immunol. 155:2269-2281.

42. Kammer, G.M., I. Khan, and C. Malemud. 1994. Deficient type I protein kinase A isozyme activity in systemic lupus erythematosus T lymphocytes. $J$. Clin. Invest. 94:422-430.

43. Berridge, M.J., R.M. Dawson, C.P. Downes, J.P. Heslop, and R.F. Irvine. 1983. Changes in the levels of inositol phosphates after agonist-dependent hydrolysis of membrane phosphoinositides. Biochem. J. 212:473-482.

44. Abney, E.R., M.D. Cooper, J.F. Kearney, and A.R. Lawton. 1978. Sequential expression of immunoglobulin in developing mouse B lymphocytes: a systematic survey that suggests a model for the generation of immunoglobulin isotype diversity. J. Immunol. 120:2041-2049.

45. Niklinska, B.B., H. Yamada, J.J. O'Shea, C.H. June, and J.D. Ashwell 1992. Tyrosine kinase regulated and inositol phosphate independent $\mathrm{Ca}^{2+}$ elevation and mobilization in T cells. J. Biol. Chem. 267:7154-7159.

46. Takata, M., H. Sabe, A. Hata, and T. Inazu. 1994. Tyrosine kinases Lyn and Syk regulate $\mathrm{B}$ cell receptor coupled $\mathrm{Ca}^{++}$mobilization through distinct pathways. EMBO J. 13:1341-1349.

47. Cooke, M.P., K.M. Abraham, K.A. Forbush, and R.M. Perlmutter 1991. Regulation of T cell receptor signaling by a src family protein-tyrosine kinase (p59 fyn $)$. Cell. 65:281-291.

48. Katagiri, T., K.Urakawa, Y. Yamanashi, K. Semba, T. Takahashi, K.Toyoshima, T. Yamamoto, and K. Kano. 1989. Overexpression of src-family gene for tyrosine-kinase $\mathrm{p} 59^{\mathrm{fyn}}$ in $\mathrm{CD} 4^{-} \mathrm{CD} 8^{-} \mathrm{T}$ cells of mice with a lymphoproliferative disorder. Proc. Natl. Acad. Sci. USA. 86:10064-10068.

49. Kim, K.M., and M. Reth. 1995. Signaling difference between class IgM and IgD antigen receptors. Ann. NY Acad. Sci. 766:81-88.

50. Wilson, H.A., D. Greenblatt, C.W.Taylor, J.W. Putney, R.Y.Tsien, F.D. Finkelman, and T.M. Chused. 1987. The B lymphocyte calcium response to anti-Ig is diminished by membrane immunoglobulin crosslinkage to the $\mathrm{Fc} \gamma$ receptor. J. Immunol. 138:1712-1718.

51. Reth, M. 1992. Antigen receptors on B lymphocytes. Annu. Rev. Immunol. 10:97-121.

52. Reth, M., J. Hombach, J. Wienands, K.S. Campbell, N. Chien, L.B. Justment, and J.C. Cambier. 1991. The B cell antigen receptor complex. Immunol. Today. 12:196-201.

53. Cambier, J.C., and K.S. Campbell. 1992. Membrane immunoglobulin and its accomplices-new lessons from an old receptor. FASEB J. 6:3207-3217.

54. Reth, M. 1989. Antigen receptor tail clue. Nature (Lond.). 338:383-384.

55. Yamanashi, Y., T. Kakiuchi, J. Mizuguchi, T. Yamamoto, and K. Toyoshima. 1991. Association of B cell antigen receptor with protein tyrosine kinase Lyn. Science (Wash. DC). 251:191-194.

56. Clark, M.R., K.S.Campbell, A. Kazlauskas, S.A. Johnson, M.Hertz, T.A. Potter, C. Pleiman, and J.C. Cambier. 1992. The B-cell antigen receptor complex-association of Ig- $\alpha$ and Ig- $\beta$ with distinct cytoplasmic effectors. Science (Wash. DC). 258:123-126.

57. Pleiman, C.M., D. D'Ambrosio, and J.C. Cambier. 1994. The B-cell antigen receptor complex: structure and signal transduction. Immunol. Today. 15 393-399.

58. Hutchcroft, J.E., M.L. Harrison, and R.L. Geahlen. 1991. B lymphocyte activation is accompanied by phosphorylation of a $72-\mathrm{kDa}$ protein tyrosine $\mathrm{ki}$ nase. J. Biol. Chem. 266:14846-14849.

59. Hutchcroft, J.E., M.L. Harrison, and R.L. Geahlen 1992. Association of the $72-\mathrm{kDa}$ protein tyrosine kinase PTK 72 with the B cell antigen receptor. $J$. Biol. Chem. 267:8613-8619.

60. Songyang, Z., S.E. Shoelson, J. McGlade, J. Olivier, T. Pawson, X.R. 
Bustelo, M. Barbacid, H. Sabe, H. Hanafusa, T. Yi et al. 1994. Specific motifs recognized by the $\mathrm{SH} 2$ domains of Csk, 3BP2, fps/fes, GRB-2, HCP, SHC, Syk and Vav. Mol. Cell Biol. 14:2777-2785.

61. Gold, M.R., L. Matsuchi, R.B. Kelly, and A.L. DeFranco. 1991. Tyrosine phosphorylation of components of the B-cell antigen receptors following receptor crosslinking. Proc. Natl. Acad. Sci. USA. 88:3436-3440.

62. Burkhardt, A.L., M. Brunswick, J.B. Bolen, and J.J. Mond. 1991. Antiimmunoglobulin stimulation of B lymphocytes activates src-related protein-tyrosine kinases. Proc. Natl. Acad. Sci. USA. 88:7410-7414.

63. Graziadei, L., K. Raibowol, and D. Bar-Sagi. 1990. Co-capping of ras proteins with surface immunoglobulins in B-lymphocytes. Nature (Lond.). 356: 396-400.

64. Padeh, S., A. Levitzki, A. Gazit, G.B. Mills, and C.M. Roifman. 1991. Activation of phospholipase $\mathrm{C}$ in human $\mathrm{B}$ cells is dependent on tyrosine phosphorylation. J. Clin. Invest. 87:1114-1118.

65. Gold, M.R., M.T. Crowley, G.A. Martin, F. McCormick, and A.L. DeFranco. 1993. Targets of lymphocyte-B antigen receptor signal transduction include the p21(ras) GTP-ase activating protein (GAP) and 2 GAP-associated proteins. J. Immunol. 150:377-386.

66. Gold, M.R., D.A. Law, and A.L. DeFranco. 1990. Stimulation of protein tyrosine phosphorylation by the B lymphocyte antigen receptor Nature (Lond.). 345:810-813.

67. Burkhardt, A.L., M. Brunswick, J.B. Bolen, and J.J. Mond. 1991. Antiimmunoglobulin stimulation of B lymphocytes activates src-related protein tyrosine kinases. Proc. Natl. Acad. Sci. USA. 88:7410-7414.

68. Ales-Martinez, J.E., D.W. Scott, R.P. Phipps, J.E. Casnellie, G. Kroemer, C. Martinez, and L. Pezzi. 1992. Crosslinking of surface IgM or IgD causes differential biological effects in spite of overlap in tyrosine (de)phosphorylation profile. Eur. J. Immunol. 22:845-850.

69. Justement, L.B., J. Wienands, J. Hombach, M. Reth, and J.C. Cambier. 1990. Membrane $\mathrm{IgM}$ and $\mathrm{IgD}$ molecules fail to transduce $\mathrm{Ca}^{++}$mobilizing signals when expressed on differentiated B lineage cells. J. Immunol. 144:32723280 .

70. Tisch, R., C.M. Roifman, and N. Hozumi. 1988. Functional differences between immunoglobulins $\mathrm{M}$ and $\mathrm{D}$ expressed on the surface of an immature B cell line. Proc. Natl. Acad. Sci. USA. 85:6914-6918.

71. Carsetti, R., G. Kohler, and M.C. Lamers. 1993. A role for immunoglobulin D: interference with tolerance induction. Eur. J. Immunol. 23:168-178.

72. Hirose, K., and M. Iino. 1995 . Heterogeneity of channel density in inositol-1,4,5,-trisphosphate-sensitive $\mathrm{Ca}^{++}$stores. Nature (Lond.). 372:791-794.

73. Kasai, H., and O. Petersen. 1994. Spatial dynamics of second messen- gers: IP3 and cAMP as long range and associative messengers. Trends. Neurosci. 17:95-101.

74. Thottala, J., K. Ondrias, E. Ondriasova, and A.R. Marks. 1996. Regulation of the inositol 1,4,5,-trisphosphate receptor by tyrosine phosphorylation. Science (Wash. DC). 272:1492-1495.

75. Papadogiannakis, N., T.E. Nordstrom, L.C. Anderson, and C.H. Wolff 1989. cAMP inhibits the OKT3-induced increase in free intracytoplasmic calcium in the Jurkat $\mathrm{T}$ cell line: the degree of inhibition correlates inversely with the amount of CD3 binding ligand used. Eur. J. Immunol. 19:1953-1956.

76. Park, D.J., H.K. Min, and S.G. Rhee. 1992. Inhibition of CD3-linked phospholipase $\mathrm{C}$ by phorbol ester and by cAMP is associated with decreased phosphotyrosine and increased phosphoserine contents of PLC-gamma 1. $J$. Biol. Chem. 267:1496-1501.

77. Alava, M.A., K.E. DeBell, A. Conti, T. Hoffman, and E. Bonvini. 1992. Increased intracellular cAMP inhibits inositol phospholipid hydrolysis induced by perturbation of the $\mathrm{T}$ cell receptor/CD3 complex but not by G-protein stimulation: association with protein kinase A-mediated phosphorylation of phospholipase C-gamma 1. Biochem. J. 284:189-199.

78. Oleson, D.R., L.J. DeFelice, M.F. Quinn, and R.M. Donahoe. 1996. cAMP increases the open probability of potassium channels in activated human T cells. J. Immunol. 157:1080-1086.

79. Premack, B.A., and P. Gardner. 1992. Signal transduction by T cell receptors: mobilization of $\mathrm{Ca}$ and regulation of $\mathrm{Ca}$-dependent effector molecules Am. J. Physol. 263:C1119-C1140.

80. Schulman, H. 1993. The multifunctional $\mathrm{Ca}^{++} /$calmodulin-dependent protein kinases. Curr. Opin. Cell Biol. 5:247-253.

81. Trump, B.F., and I.K. Berezesky. 1992. The role of cytosolic $\mathrm{Ca}^{++}$in cell injury,necrosis and apoptosis. Curr. Opin. Cell Biol. 4:227-232.

82. Linker-Israeli, M. 1992. Cytokine abnormalities in human lupus. Clin. Immunol. Immunopathol. 63:10-12.

83. Emlen, W., J. Niebur, and R. Kadera. 1994. Accelerated in vitro apoptosis of lymphocytes from patients with systemic lupus erythematosus. J. Immunol. $152: 3685-3692$.

84. Russell, J.H., B. Rush, C. Weaver, and R.Wang. 1993. Mature T cells from autoimmune lpr/lpr mice have a defect in antigen-stimulated suicide. Proc. Natl. Acad. Sci. USA. 90:4409-4413.

85. Bossu, P., G.G. Singer, P. Andres, R. Ettinger, A. Marshak-Rothstein, and A.K. Abbas. 1993. Mature $\mathrm{CD}^{+}{ }^{+}$T lymphocytes from MLR/lpr mice are resistant to receptor-mediated tolerance and apoptosis. J. Immunol. 151:72337239. 